\title{
ПРИРОДНЫЕ ФАКТОРЫ ВОЗНИКНОВЕНИЯ ЛЕСНЫХ ПОЖАРОВ НА ТЕРРИТОРИИ ИРКУТСКОЙ ОБЛАСТИ Е.П. Белоусова ${ }^{1}$, И.В. Латышева ${ }^{2 *}$, С.В. Латышев ${ }^{1}$, К.А. Лощенко ${ }^{2}$, А.С. Щеблыкин ${ }^{2}$ \\ ${ }^{1}$ Институт солнечно-земной физики СО РАН и ${ }^{2}$ Иркутский государственный университет,

\author{
Иркутск, Россия \\ *Эл.nочma:ababab1967@mail.ru \\ Статья поступила в редакиию 12.07.2016; принята к печати 12.10.2016
}

Проанализированы данные о вкладе метеорологических и синоптических условий в возникновение лесных пожаров в Иркутской области. По результатам наблюдений метеорологических станций, расположенных в разных физико-географических районах Иркутской области, рассчитан показатель пожарной опасности по В.Г. Нестерову в периоды апрель-сентябрь $2010-2015$ гг. Этот показатель характеризует метеорологические условия исследуемой территории как усредненные по степени пожарной опасности. Выявлено, что наиболее благоприятные условия для возникновения лесных пожаров по времени наблюдаются в мае-июне и августесентябре, а в пространственном отношении - на севере Иркутской области и на побережье оз. Байкал, где отмечается наименьшее количество атмосферных осадков. Синоптический анализ летнего периода 2015 г. с большим числом лесных пожаров на Байкальской природной территории показал господствующее влияние блокирующих процессов, которые сопровождались редким выходом южных циклонов - основных поставщиков влаги в регион. В качестве предикторов лесных пожаров в Иркутской области наиболее высокую оправдываемость $(\geq 70 \%)$ в теплый период 2015 г. имели значения температуры воздуха: у поверхности Земли, в нижней (АТ-850 гПа) и средней (АТ-500 гПа) тропосфере, потенциальной температуры на уровне АТ-850 гПа; аномалии геопотенциала АТ-500 гПа, относительной влажности воздуха и сумм атмосферных осадков.

Ключевые слова: лесные пожары, метеорологические условия, Иркутская область.

\section{NATURAL FACTORS OF FOREST FIRES IN IRKUTSK OBLAST}

Ye.P. Belousova ${ }^{1}$, I.V. Latysheva ${ }^{2 *}$, S.V. Latyshev ${ }^{1}$, K.A. Loshchenko ${ }^{2}$, A.S. Shcheblykin ${ }^{2}$

${ }^{1}$ Institute of Solar-Terrestrial Physics of the Siberian Branch of the Russian Academy of Sciences and

${ }^{2}$ Irkutsk State University, Irkutsk, Russia

E-mail:ababab1967@mail.ru

The contribution of meteorological and synoptic conditions to the occurrence of forest fires in Irkutsk Oblast is assessed. Based on observations at meteorological stations located in different physiographic regions of Irkutsk Oblast, the index of fire danger according to N.P. Nesterov is calculated for the periods ranging from April through September in the years 2010-2015. The index characterizes the meteorological conditions in the area of interest as the averaged degree of fire hazard. The most favorable times for forest fires are May-June and AugustSeptember, and the most favorable areas are in the northern part of Irkutsk Oblast and at the coast of the lake Baikal, where the amount of rainfalls is the least. The synoptic analysis of summer in 2015, when forest fires in the territories near Baikal were numerous, revealed the dominant role of blocking processes accompanied by rare southern cyclones, which are the main suppliers of moisture to the region. The most accurate predictors of forest fires in Irkutsk Oblast ( $\geq 70 \%$ accuracy) in the warm season of 2015 were air temperatures at the ground level and at tropospheric heights AT- $850 \mathrm{hPa}$ and $\mathrm{AT}-\mathbf{5 0 0} \mathrm{hPa}$, potential temperatures at AT-850 hPa, geopotential anomalies at AT-500 $\mathrm{hPa}$, and relative humidity and total precipitations.

Keywords: forest fires, weather conditions, Irkutsk Oblast.

\section{Введение}

Ежегодно на территории России возникают 1030 тыс. лесных пожаров, охватывающих площадь от 0,5 до 2 млн га. Лесные пожары приводят к региональным биосферным изменениям, изменениям альбедо и радиационного баланса подстилающей поверхности, углеродного обмена между атмосферой и наземными экосистемами, эрозии почв, уничтожению фитомассы лесных биогеоценозов и разрушению сложившихся экосистем. По оценке геобиоцентра Мюнхенского университета (Германия) в результате лесных и торфяных пожаров на территории России только в 2010 г. в атмосферу было выброшено от 30 до 100 млн тонн двуокиси углерода. Задымление территории при возникновении лесных пожаров оказывает негативное влияние на качество атмосферного возду- ха и здоровье населения, способствует ухудшению горизонтальной дальности видимости и нарушению режима движения различных видов транспорта [19].

Горение лесных горючих материалов (ЛГМ) влияет на атмосферные процессы. Дымовые частицы служат ядрами конденсации водяного пара, коагуляции и кристаллизации водяных капель. Активный вертикальный тепломассоперенос, генерируемый в зоне массовых лесных пожаров, по данным [5], может вызвать изменение атмосферной циркуляции синоптического масштаба, а выбросы диоксида углерода и других парниковых газов, выделяющихся при пожаpe, способствовать парниковому эффекту [41]. В настоящее время отмечается увеличение количества лесных пожаров и пройденной ими площади на территории России (рис. 1). 


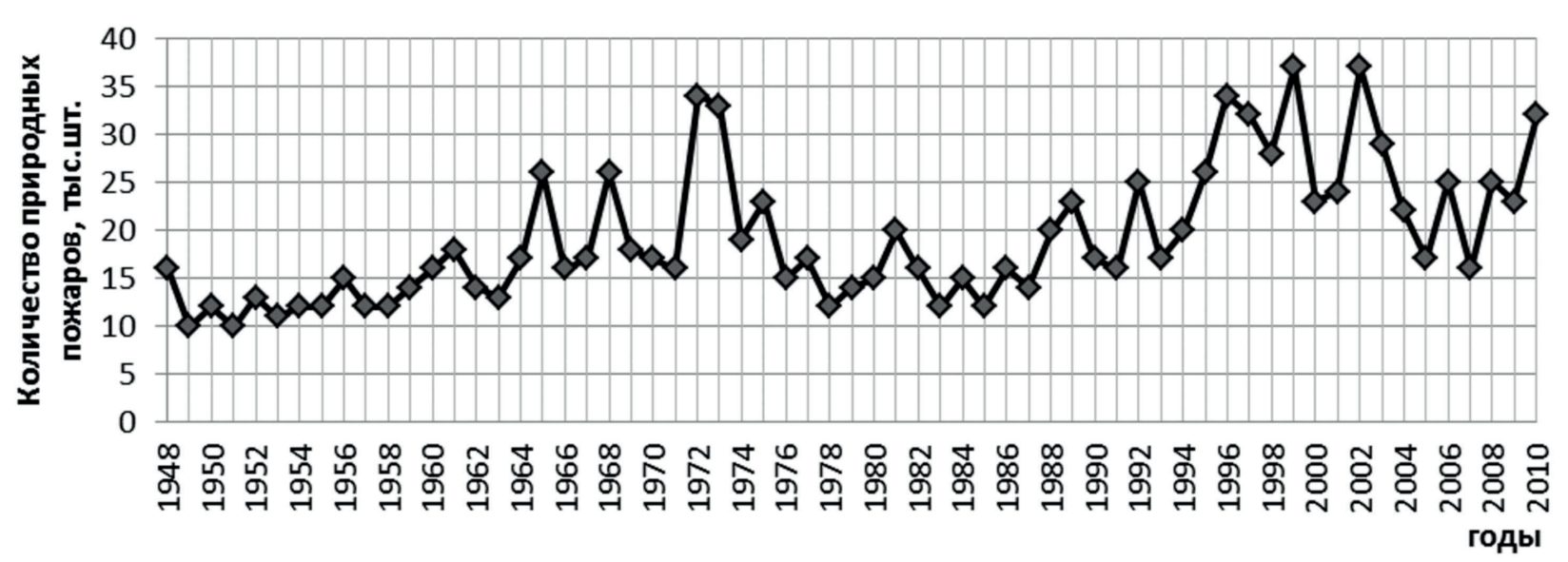

Рис. 1. Динамика количества природных пожаров на территории России за 1948-2010 гг.

(до 1996 г. - данные Федеральной службы лесного хозяйства, для более поздних лет информация получена на основе спутникового мониторинга)

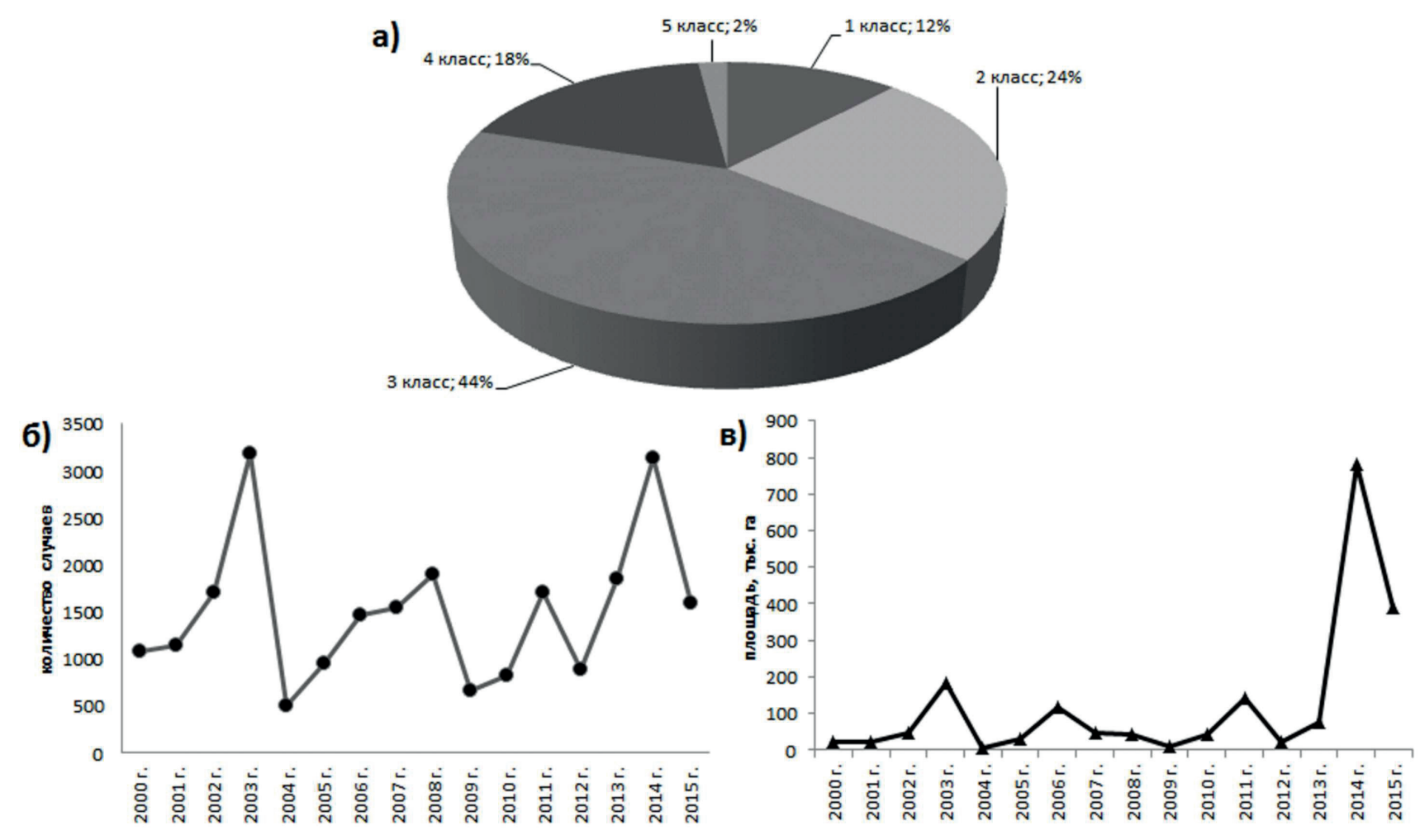

Рис. 2. Распределение лесного фонда агентства лесного хозяйства Иркутской области по классам природной пожарной опасности (а), динамика количества лесных пожаров (б) и выгоревшей лесной площади (в) в Иркутской области в 2003-2015 гг. [43]

Иркутская область занимает площадь 767,9 тыс. км² (4,6\% территории России). По данным государственного лесного реестра, около $80 \%$ территории области занято лесами, $11 \%$ которых представлено кедровым древостоем. Здесь сосредоточено около $12 \%$ запасов древесины спелых лесов страны, а доля особо ценных хвойных пород, таких как сосна и кедр, значительна даже в масштабах планеты. Примерно 36\% лесного фонда Иркутской области характеризуются высокой степенью природной пожарной опасности (рис. 2a). Динамика числа лесных пожаров характеризуется значительной межгодовой изменчивостью (рис. 2б). Обращает внимание увеличение выгоревшей лесной площади в 2014-2015 гг. (рис. 2в). По данным на 10.06.2016, на территории Российской Федерации действовало 67 лесных пожаров на площади 6306 га, из них 8 пожаров на площуад 1465 га отмечалось на землях лесного фонда Иркутской области.

Важнейшим принципом экологически устойчивого и социально ответственного лесопользования на территории Иркутской области является сохранение и улучшение средообразующих, природоохранных и социальных функций лесов, обеспечение возможности не уменьшающегося использования древесных лесных ресурсов в будущем. В этой связи представ- 
ляет интерес изучение природных факторов возникновения лесных пожаров на территории Иркутской области, что определило цель и актуальность выполненного исследования.

\section{Объекты и методы изучения природных факторов лесных пожаров}

Лесные пожары - это горение растительности, которое не поддается контролю и стихийно распространяется по территории массива. Опасность лесных пожаров заключается в быстром и стихийном распространении, а последствия - в длительном восстановлении флоры и нанесении экологического, экономического и материального ущерба [12].

В настоящее время приняты различные классификации лесных пожаров. В зависимости от площади возможно: загорание, когда огнем охвачено 0,1-2 га, малый пожар (от 2 до 20 га), средний (от 20 до 200 га), крупный (от 20 до 2000 га) и катастрофический (>2000 га). В качестве примеров катастрофических лесных пожаров на территории России за последние десятилетия можно привести лесной пожар в Республике Бурятия с 4 июля по 2 августа 2010 г., когда огнем было охвачено более 75000 га территории, покрытой лесом, в Республике Саха (Якутия) с 9 июня по 27 августа 2002 г., когда пострадало 272000 га площади, покрытой лесом.

Лесные пожары подразделяют на низовые, верховые и торфяные. Примерно 90\% общего числа лесных пожаров составляют низовые пожары, скорость распространения которых - 2,5-3,0 м/мин. Наиболее устойчивы летние и летне-осенние низовые пожары, которые нередко уничтожают напочвенный покров, подлесок, весь слой гумуса и поверхностные корни древесных пород. Осенние низовые пожары развиваются в основном в дневное время, так как ночью изза низких температур воздуха и высокой влажности горение замедляется и частично прекращается. Верховые пожары характеризуются быстрым продвижением огня по кронам деревьев при сильном ветре. Скорость верхового пожара иногда достигает 400500 м/мин. Специфика торфяных пожаров - в выделении большого количества дыма, скорость их распространения составляет несколько метров в сутки.

Основные причины возникновения лесных пожаров делятся на естественные и антропогенные. В зависимости от степени освоенности территории, плотности проживающего населения и климатообразующих факторов, может превалировать одна из указанных причин. Чаще возникновение лесных пожаров связывают с антропогенным фактором. Отмечено увеличение частоты лесных пожаров в выходные дни [7]. Однако в отдельных регионах (например, северные районы Красноярского края, территория Якутии) доля пожаров от гроз может достигать 90\% [10]. По данным В.А. Иванова [8], от разрядов молний в среднем по России ежегодно возникает около $10 \%$ лесных пожаров. Первостепенное значение в условиях, определяющих возможность возникновения и распространения пожаров от молний, имеет влажность ЛГМ, зависящая от погодных условий.

При оценке пожарной опасности растительности необходимо учитывать сумму постоянных и переменных факторов, влияющих на начало горения и распространение пожара. При анализе предрасположенности территории к возникновению лесных пожаров исследуют прежде всего пирологические характеристики климата и растительности. Под пирологической характеристикой климата понимают «оценку типичного хода погоды, определяющую типичный ход развития растительности и сезонных изменений пожарной опасности в регионе» [22]. К основным характеристикам климата, влияющим на пожарную опасность, относятся: температура воздуха (среднесуточная и максимальная), даты перехода средних суточных температур через пороговые пределы, даты наступления и схода устойчивого снежного покрова, относительная влажность (среднесуточная и минимальная), дефицит влажности воздуха, число дней с относительной влажностью $\leq 30 \%$ в один из сроков наблюдения за определенный период, годовой режим выпадения атмосферных осадков, число дней с дождем, индекс сухости, ветровой режим, число дней с грозой [25].

Совместный анализ распределения температуры воздуха и количества атмосферных осадков показывает, что пожароопасность весеннего и осеннего периодов на территории России определяется сочетанием положительных температур с низким количеством атмосферных осадков, между которыми находится летний период, особенно июль-август, с высокими температурами и значительными осадками и пониженной вероятностью возникновения пожаров. Значительное воздействие на процессы высыхания ЛГМ оказывает ветровой режим. К пирологическим характеристикам климата относят грозовую активность, которая определяет количество природных источников пожаров растительности [27]. Анализ данных о причинах возгорания за 38-летний период на территории Лено-Амгинского междуречья показал, что основной причиной лесных пожаров являются «сухие грозы» в июле и августе $(38,3 \%)$ [4].

В настоящее время предложено большое число показателей, в которых пожарная опасность оценивается на основе эмпирических зависимостей, учитывающих метеорологические данные, которые определяют процессы высыхания и увлажнения ЛГМ. Показатели рассчитываются на различных пространственных и временных масштабах и характеризуют атмосферные условия, сказывающиеся как на возгорании, так и на распространении лесных пожаров. В России широко используется комплексный показатель пожарной опасности В.Г. Нестерова, предложенный в 1940-е гг. [18], и его модификации, разработанные для континентального климата, с поправками на гигроскопичность ЛГМ [22], учитывающие дефицит упругости насыщения водяного пара в атмосфере [6], объем выпавших осадков [28] и скорость ветра [21]. Также применяют логарифмический показатель, учитывающий метеорологические особенности различных географических районов, связанные с низкими температурами в начале и в конце пожароопасного сезона [24], показатель влажности (ПВ-1), полученный на основе экспериментальных исследований зависимости изменений послойной влажности ЛГМ от метеорологических факторов [3], и другие показатели. Среди зарубежных можно выделить австралийский индекс FFDM, испанский индекс ICONA и итальянские индексы IMPI, полученные по модели Мак Артура и учитывающие температуру, влажность воздуха, скорость ветра и уклон местности [32]; канадский индекс FWI [40], француз- 
ские метеорологические индексы Numerical Risk и ORIEUX [39], финский метеорологический индекс FMI [36] и канадский индекс FWI [40], которые отражают ежедневное изменение влагосодержания почв и ЛГM; португальский индекс PORT, который является модифицированным показателем В.Г. Нестерова с учетом суточных поправок на осадки и скорость ветра [35].

В работе [31] по данным ВНИИГМИ [45] использована модификация индекса Нестерова $\left(I_{F}\right)$ :

$$
I_{F}=\sum_{P<3 m m} T_{\max } \times\left(T_{\max }-T_{\text {dew }}\right),(1)
$$

где: $T_{\max }$ - максимальная суточная температура воздуха, ${ }^{\circ} \mathrm{C} ; T_{d e w}-$ температура точки росы, ${ }^{\circ} \mathrm{C} ; \mathrm{P}-$ количество осадков, мм. Значения индекса пожароопасности считаются умеренными, высокими и очень высокими, если изменяются от 300 до 1000, от 1000 до 4000 и выше 4000 соответственно. Средние значения индекса за период 1961-2000 гг. в Иркутске составили 1568, что соответствует высокому уровню пожароопасности. В соответствии с прогностическими данными в XXI в. при глобальном потеплении на азиатской территории России следует ожидать существенного роста вероятности лесных пожаров. В отдельных регионах, главным образом на юге, риск пожароопасности при достаточно агрессивном антропогенном сценарии уже к середине XXI в. может увеличиться троекратно по сравнению с концом XX в. Проявляется увеличение длительности пожароопасного периода с тенденцией смещения пика пожароопасности с конца лета к середине. По данным [5], межпожарный интервал на территории Сибири сократился на треть в $\mathrm{XX}$ в. по сравнению с XIX в.

Существенное влияние на возникновение лесных пожаров оказывает увеличение численности населения планеты. Однако доминирующим динамическим фактором являются погодные и климатические изменения, на что указывает большое число исследований, выполненных за последние десятилетия в различных регионах земного шара $[34,37,42]$. Многие отечественные и зарубежные исследователи отмечают, что особенности климатических изменений последних десятилетий в сторону потепления существенно усиливают угрозу возникновения крупных и катастрофических пожаров в бореальных лесах Евразии [26]. Изменение динамики горимости бореальных лесов можно проследить, если сравнить горимость лесов в обычные годы и в период длительных засух, когда недобор осадков составляет $60-80 \%$ от нормы, а средняя температура пожароопасного сезона повышается на $4-5^{\circ} \mathrm{C}$. В таких условиях резко возрастет число крупных лесных пожаров, а их площади увеличатся в десятки раз. Особенности климатических изменений в сторону потепления могут увеличить частоту засух в горных лесах юга Сибири и повысить здесь угрозу разрушительных пожаров [11].

Развитию режимов засух и пожаров способствует то, что в теплые месяцы года с ростом температуры общее количество осадков в целом уменьшается, и увеличивается роль континентальных блокингов $[16,17]$. В настоящее время выделяется периодичность пожароопасных сезонов с экстремальными погодными условиями 2-3 раза за десятилетие [2]. Под экстремальными погодными условиями понимают засуху, которая характеризуется длительным бездождевым периодом, высокими температурами, низкой относительной влажностью воздуха и сильными ветрами [30]. В экстремальные погодные периоды в двух-трех регионах страны с наиболее неблагоприятными погодными условиями лесные пожары нередко принимают характер стихийного бедствия. Одним из факторов изменения частоты природных пожаров при климатических изменениях может быть изменение числа гроз и связанных с ними молниевых ударов, которые служат одним из источников возгорания при природных пожарах [15]

Тем не менее, результаты палеоэкологических исследований не обнаруживают четкой закономерности в изменениях температуры воздуха, количества атмосферных осадков и частоты лесных пожаров [38]. Более того, повышение температуры коррелируют как положительно, так и отрицательно с изменениями осадков и лесными пожарами [33]. Учитывая сложный характер взаимодействия между погодными, климатическими и орографическими факторами, растительностью и лесными пожарами, актуальность региональных исследований возникновения лесных пожаров не вызывает сомнений.

\section{Факторы возникновения лесных пожаров в Иркутской области}

Значительная лесистость, сложная орография, различия в климатических, растительных, социальноэкономических показателях горных, предгорных и равнинных районов сложным образом сказываются на процессах формирования условий, от которых зависят частота, интенсивность и распространенность лесных пожаров на территории Иркутской области. Согласно ранее проведенным исследованиям, пожары существенно изменили облик таежных лесов Средней Сибири. По данным А.В. Побединского [20], на громадных территориях Среднесибирского плоскогорья в результате пирогенного воздействия произошла смена темнохвойных пород на светлохвойные, образовались обширные площади лиственных лесов. В Приангарье относительно частые низовые пожары препятствуют восстановлению ели, пихты, кедра, постоянно уничтожая их подрост и второй ярус в современных сосняках и лиственничниках [1]. А.С. Исаевым и А.И. Уткиным установлено, что строение лиственничников, высоко поднятые кроны и особенности пожарных периодов в регионе обусловливают преобладание низовых пожаров, на долю которых приходится более 95\% всех случаев [9]. Эпизодические сильные пожары в предгольцовых лиственничниках бассейна оз. Байкал приводят к понижению верхней границы леса [14]. В целом, наиболее мощные пожары отмечаются в мае-июне на фоне многочисленных мелких возгораний [23].

В работе [29] по ширине годичных колец удалось установить даты возникновения лесных пожаров на территории Иркутской области вплоть до XVIII в. Обнаружено, что начиная с XX в. пожары в разных районах Иркутской области стали носить практически одновременный характер, что подтверждает антропогенную причину их возникновения. Кроме того, выявлена периодичность лесных пожаров: 3-4, 11, 61-62 года, зависящая от количества атмосферных осадков в мае-июне. Обращает внимание, что предполагаемые по выявленным циклам годы максимумов пожаров с 2012 по 2015 г. совпали с ката- 
строфическими пожарами на территории Иркутской области летом 2015 г.

Для исследования метеорологических условий, определяющих возникновение лесных пожаров на территории Иркутской области, был рассчитан показатель пожарной опасности (КП) по Н.П. Нестерову по данным наблюдений метеорологических станций: Непа (59 ${ }^{\circ}$ с. ш., $108^{\circ}$ в. д.), Братск (56 ${ }^{\circ}$ с. ш., $101^{\circ}$ в. д.) и Иркутск $\left(52^{\circ}\right.$ с. ш., $104^{\circ}$ в. д.), расположенных соответственно в северном, центральном и южном районах Иркутской области, а также ст. Хужир (53ㄷ. ш., $107^{\circ}$ в. д.), находящейся в средней части оз. Байкал (рис. $3 a$ ). Выявлено, что наибольшие средние значения данного показателя в период апрель-сентябрь 2010-2015 гг. отмечались на ст. Непа (2259), что соответствует средней степени пожарной опасности. Наименьшие средние значения отмечались на ст. Братск (957), что соответствует малой степени пожарной опасности.

В Иркутске во все месяцы теплого периода отмечается средняя степень пожарной опасности с максимальными значениями в июне, в Братске во все месяцы, кроме июня - малая, в июне - средняя степень пожарной опасности (рис. 3б). В Непе во все месяцы, кроме апреля, отмечается средняя степень, в апреле - малая степень пожарной опасности. На ст. Хужир степень пожарной опасности изменяется от малой в апреле, с мая по август отмечается средняя степень пожарной опасности, в сентябре высокая степень пожарной опасности. В Непе, Иркутске и Хужире степень пожарной опасности увеличивается с апреля по июнь, в июле уменьшается, а в августе и сентябре вновь увеличивается. В Братске увеличивается с апреля по июнь, затем уменьшается.

Таким образом, метеорологические условия территории Иркутской области в апреле-сентябре 2010-2015 гг. характеризуются от малой до высокой степенью пожарной опасности. Выделяются два периода метеорологических условий, способствующих возникновению лесных пожаров на территории Иркутской области: май-июнь и август-сентябрь.

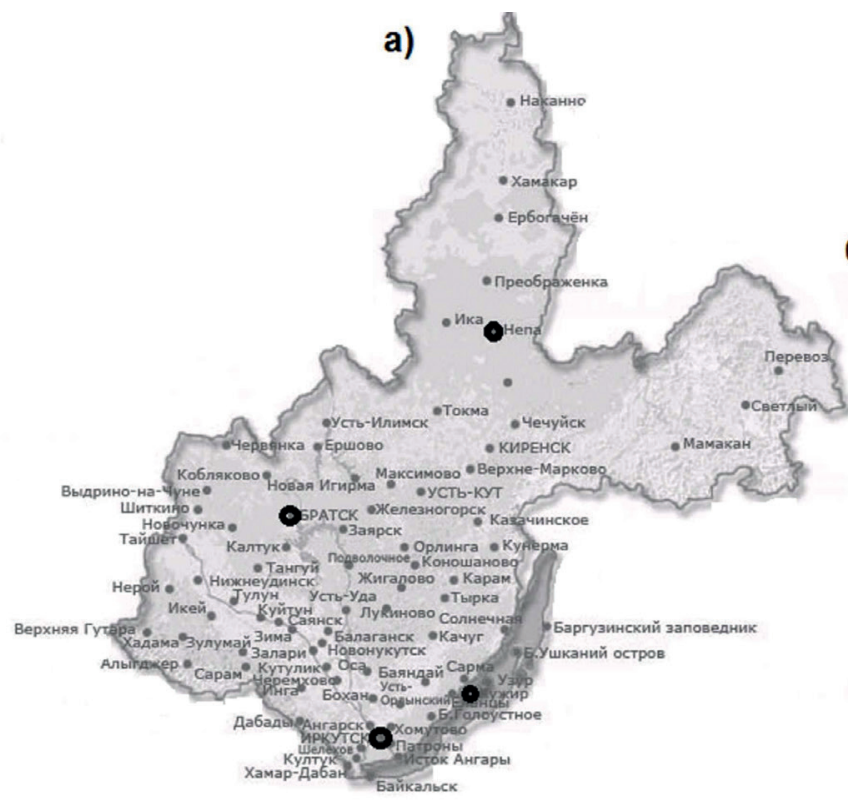

В пространственном отношении чаще всего возникновение лесных пожаров возможно в северном районе Иркутской области и на побережье оз. Байкал. Одной из причин высокой вероятности лесных пожаров в Северном районе и на побережье оз. Байкал является меньшее количество атмосферных осадков, что наглядно видно на рис. 4.

Интерес для исследования представляет теплый период 2015 г., когда на Байкальской природной территории отмечалась сильная засуха и большое количество лесных пожаров. По данным Рослесхоза [46], в 2015 г. в России зафиксировано более 11,8 тыс. лесных пожаров на площади 2,6 млн га. Более 90\% пройденной огнем площади пришлось на пять регионов Забайкалье, Бурятию, Иркутскую область, Тыву и Красноярский край. На рис. 5 показано распределение количества пожаров и горячих точек возгорания в дни, когда наибольшее число пожаров в России в теплый период 2015 г. было зарегистрировано на территории Иркутской области. Следует указать, что летние пожары 2015 г. сохранялись в августе, когда по многолетним данным на территории Иркутской области отмечаются частые выходы южных циклонов (монгольские циклоны), сопровождающиеся значительными осадками. На рис. 6 показаны очаги возгорания, которые в августе 2015 г. занимали значительную площадь побережья оз. Байкал.

Анализ причин длительной засушливой погоды и большого количества лесных пожаров на Байкальской природной территории в теплый период 2015 г. показал следующее. По данным Гидрометцентра России [47], возникновению лесных пожаров предшествовали низкие снегозапасы и положительные отклонения среднемесячной температуры воздуха в марте-мае 2015 г. от климатической нормы на $3-6^{\circ} \mathrm{C}$, которые способствовали высыханию растительности, росту количества очагов природных пожаров и распространению их на большие площади. В теплый период 2015 г. в значительной толще тропосфере над Сибирью сохранялась блокирующая ситуация, которая препятствовала выходу циклонов и выпадению

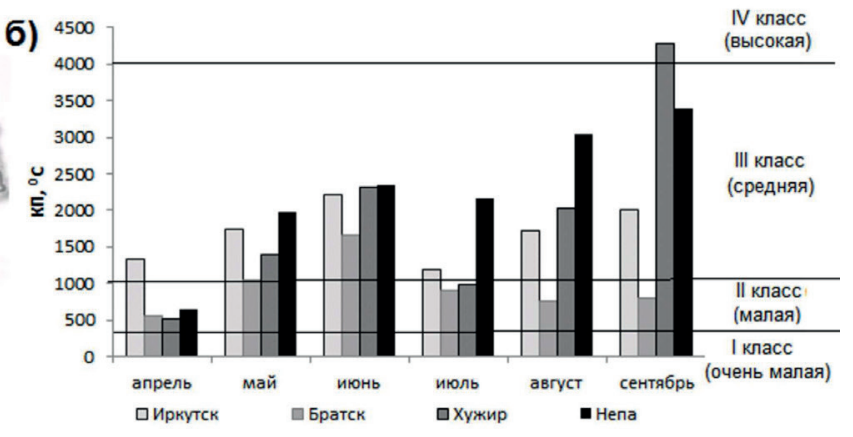

Рис. 3. Схема метеорологических станций Иркутской области (а) и средние значения показателя пожарной опасности (КП) по В.Г. Нестерову за 2010-2015 гг. (б) 

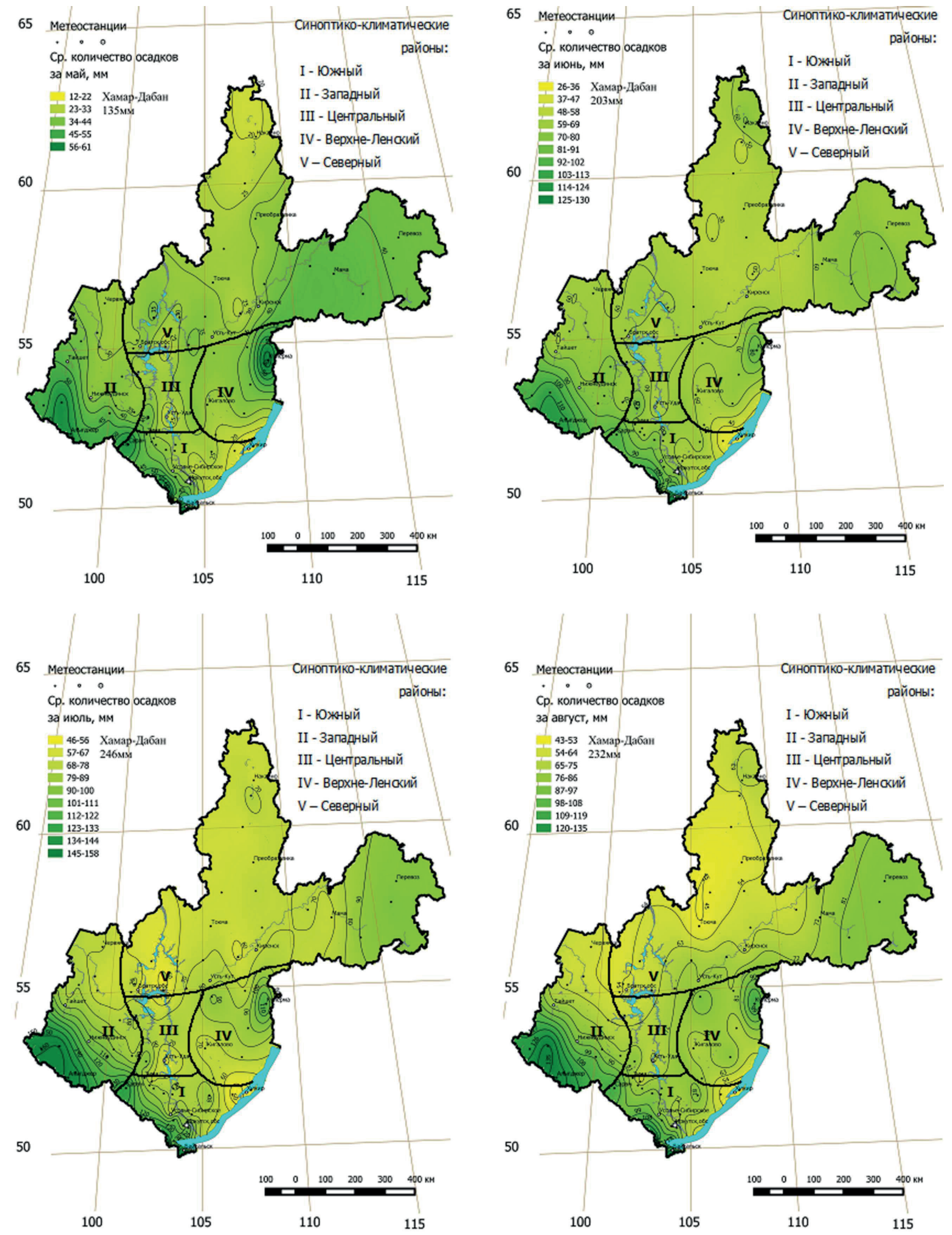

Рис. 4. Средние значения сумм атмосферных осадков (Мм) в различные месяцы теплого периода 2010-2015 гг. на территории Иркутской области (построено по данным 81 метеорологической станции) 
a)

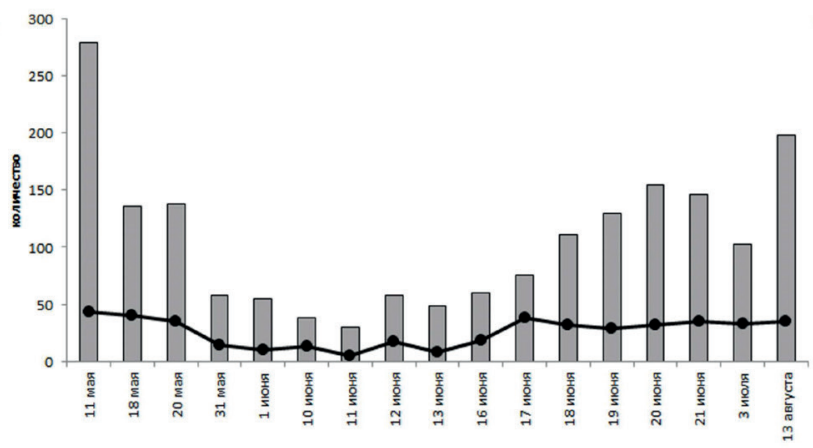

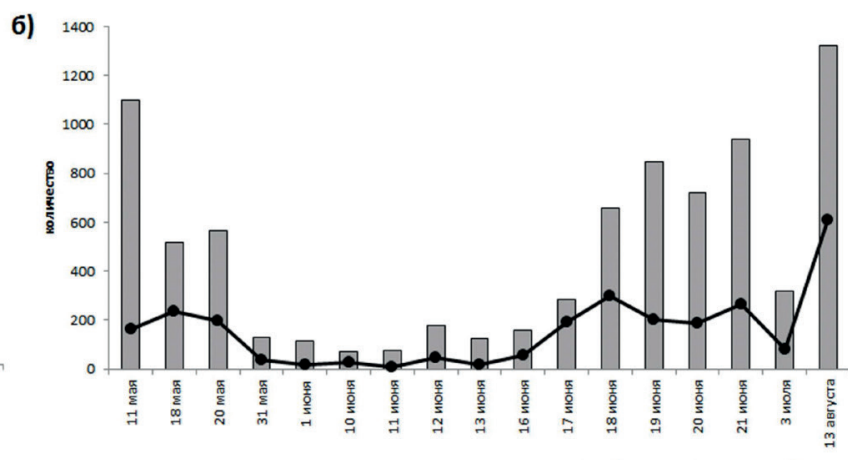

Рис. 5. Распределение количества пожаров (а) и горячих точек возгорания (б) на территории России и Иркутской области в теплый период 2015 г.

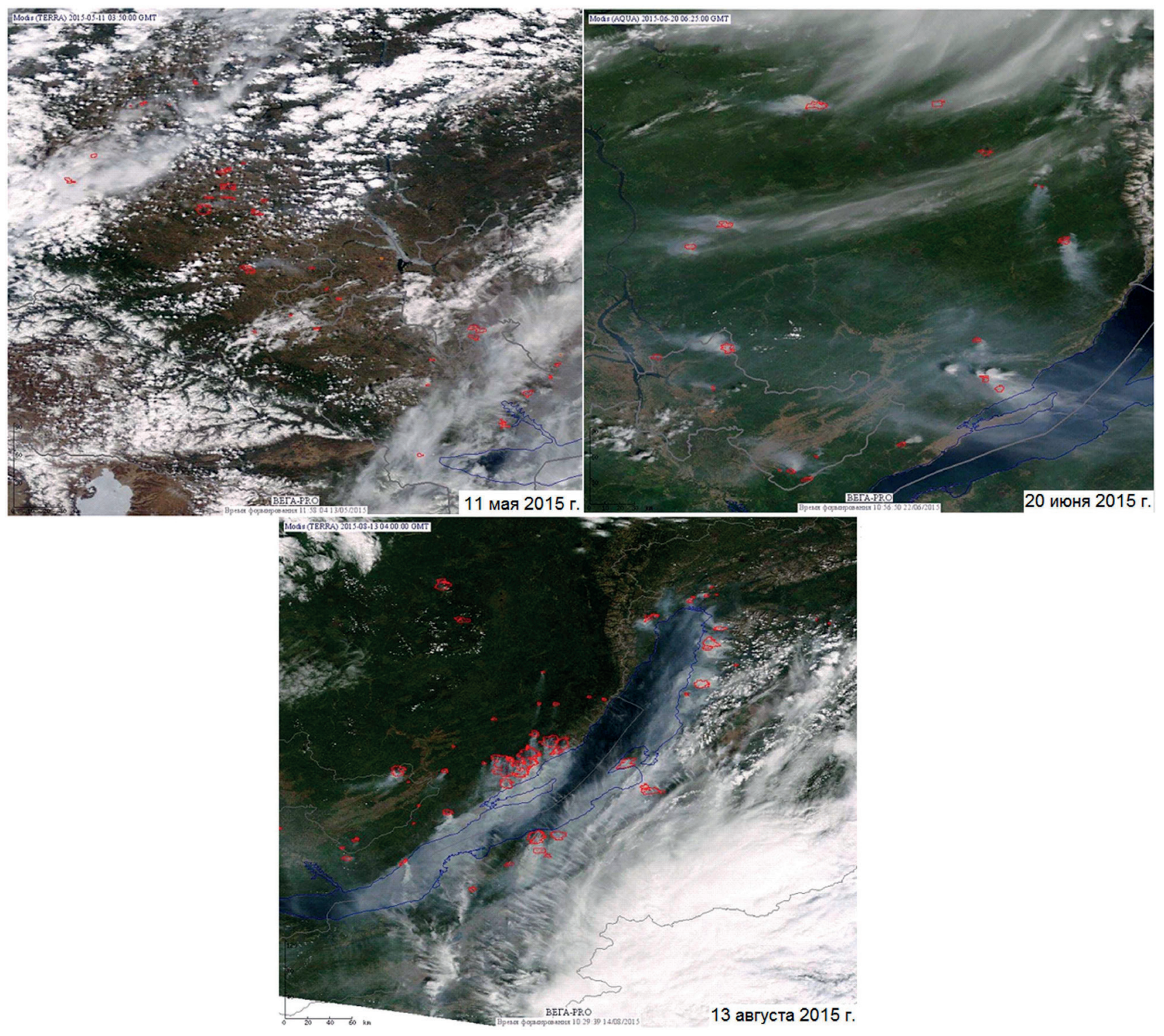

Pис. 6. Пожарная ситуация на Байкальской территории по данным спутников Terra и Aqua [44] 
атмосферных осадков на территории Иркутской области. Анализ ежедневных синоптических карт показал, что по сравнению с многолетними данными 2000-2013 гг. [13] в теплый период 2015 г. на Байкальской территории в 3 раза реже наблюдались выходы южных циклонов - основных поставщиков влаги в регион и в 4 раза чаще теплый сектор и передняя часть ныряющих циклонов, где осуществляется адвекция теплых и сухих воздушных масс (рис. 7).

В настоящее время в летний сезон оперативнопрогностические организации составляют прогнозы классов пожарной опасности на трое суток и месяц. Однако хорошей методической базы для подготовки и выпуска этих прогнозов не имеют. Причиной является невысокая оправдываемость прогностических полей приземной температуры воздуха, температуры точки росы и количества атмосферных осадков.

Потенциальные предикторы должны отражать физическую связь с исследуемым объектом, и их значения должны быть известны к началу оперативных расчетов прогнозов. На достаточно высоком уровне по динамическим уравнениям прогнозируются только поля приземного давления, геопотенциала изобарической поверхности АТ-500 гПа и температуры воздуха на уровне изобарической поверхности AT-850 гПа, причем на 1-5 сут. Именно эти параметры и их производные в различных формах привлекаются в качестве предикторов в физико-статистических схемах.

Анализ прогностических карт Национального центра США прогноза окружающей среды (NCEP/NCAR), начиная с февраля 2014 г., выполненный для территории Иркутской области на пожароопасный период 2015 г., показал следующее. В качестве предикторов возникновения пожаров, которые имели высокую оправдываемость ( $\geq 70 \%)$, можно рассматривать прогностические значения температуры воздуха: у поверхности Земли, в нижней (AТ-850 гПа) и средней (AT-500 гПа) тропосфере и потенциальной температуры на уровне АТ-850 гПа. Именно повышенные значения температур в значительной толще тропосферы сопровождались развитием в летние месяцы 2015 г. над территорией Иркутской области блокирующих процессов, что подтверждают положительные аномалии геопотенциала (АТ-500 гПа +8 декаметров). В условиях длительного стационирования антициклонов наблюдались отрицательные аномалии относительной влажности воздуха и сумм атмосферных осадков, то есть прогнозировалось формирование на территории Иркутской области летнего жаркого засушливого периода, благоприятного для возникновения и распространения лесных пожаров.

По данным ФБУ «Центральная база авиационной охраны лесов “Авиалесоохрана”» на основании данных долгосрочного прогноза температуры и осадков от Гидрометцентра России на период апрель-август 2016 г. и результатов многомерного корреляционного анализа разработан долгосрочный прогноз, согласно которому повышенная вероятность превышения среднемноголетних значений параметров пожарной опасности на территории Иркутской области прогнозируется в 2016 г. в июне в северной и южной части области и в июле в северной, северо-западной и центральной части. Следует отметить, что прогноз оправдался. По данным Минприроды РФ на конец июля 2016 г. Иркутская область, наряду с Красноярским краем, Ямало-Ненецким АО, республиками Бурятия и Саха (Якутия) вошли в пятерку наиболее «горимых» регионов, на долю которых приходится около 34\% общей площади лесных пожаров РФ.

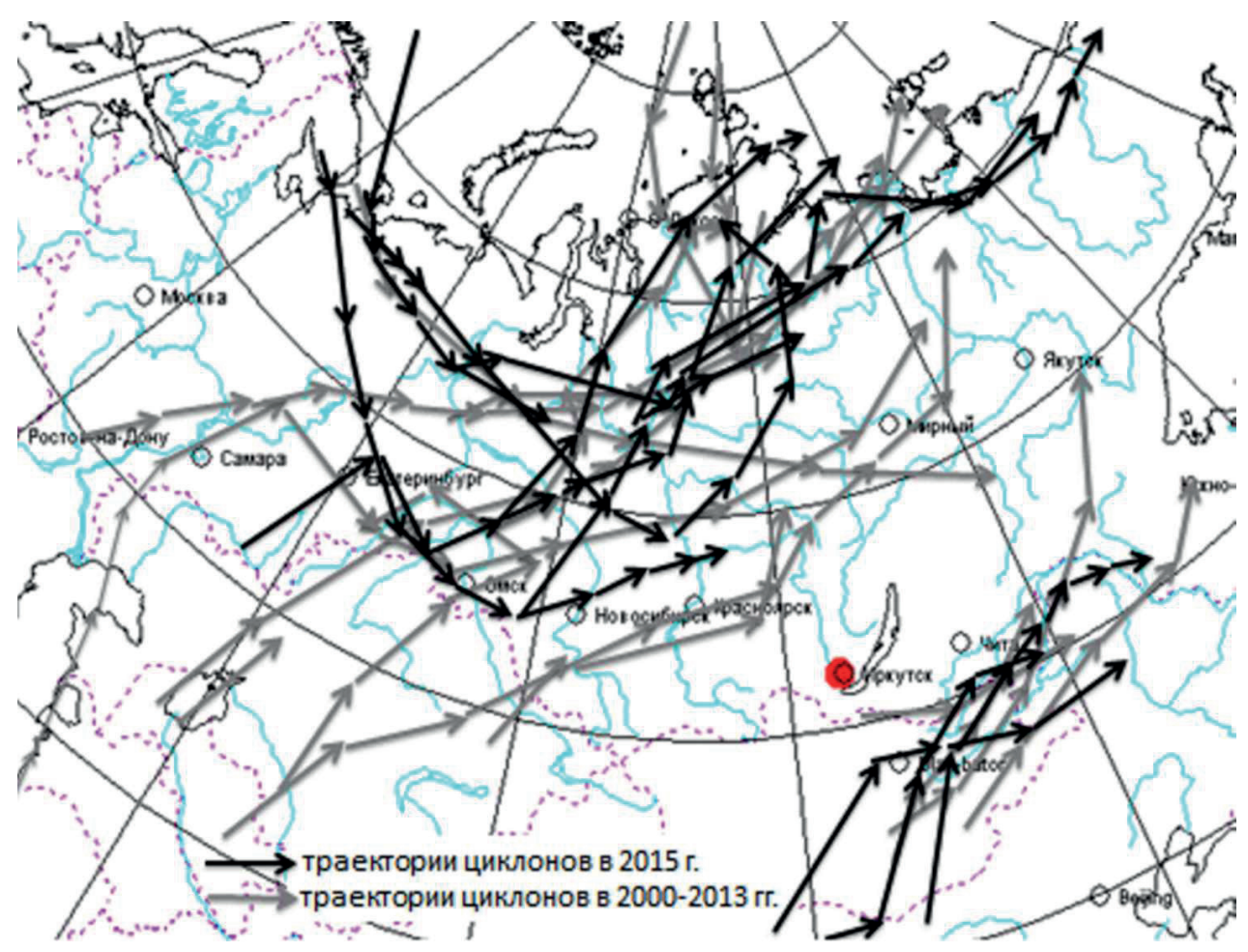

Рис. 7. Траектории циклонов, оказывающих влияние на погодные условия Иркутской области в теплый период 2000-2013 гг. и 2015 г. 


\section{Заключение}

Проведен анализ метеорологических условий возникновения лесных пожаров на территории Иркутской области, 80\% территории которой занято лесами, а доля ценных хвойных пород значительна в масштабах планеты. Установлено, что современные тенденции изменений климата характеризуются увеличением повторяемости засушливых условий, которые приводят к увеличению частоты лесных пожаров на территории Иркутской области.

Существенный вклад в возникновение лесных пожаров на исследуемой территории принадлежит погодным и климатическим факторам. На примере аномально засушливого летнего периода 2015 г. установлено, что одной из причин высокой пожароопасности явилось аномальное развитие синоптических процессов, которое на фоне уменьшения повторяемости холодных фронтов и увеличения повторяемости передних частей циклонов способствовало длительному сохранению теплых сухих воздушных масс в регионе. Кратковременные ливни 2015 г. не смогли полностью погасить лесные пожары.

Рассмотрены пространственно-временные изменения основных метеорологических показателей, определяющих пожароопасность растительности. Выявлено, что метеорологические условия, благоприятные для возникновения и распространения лесных пожаров, чаще всего отмечаются в мае-июне и августе-сентябре. К территориям, наиболее подверженным возникновению лесных пожаров по погодным и климатическим факторам, относятся северные районы и побережье оз. Байкал, где расположены природоохранные зоны, что следует учитывать при оценке природных факторов экологических рисков на исследуемой территории.

Работа выполнена при поддержке гранта для аспирантов и молодых сотрудников ИГУ № 091-15-228 от 13.11.2015.

\section{Литература}

\section{Список русскоязычной литературы}

1. Бузыкин АИ, Пшеничникова ЛС. Формирование сосново-лиственных молодняков. Новосибирск: Наука; 1980.

2. Валендик ЭН. Борьба с крупными пожарами. Новосибирск: Наука; 1990.

3. Вонский СН, Жданко ВА, Корбут ВИ. Определение природной пожарной опасности в лесу. Л.: ЛенНИИЛХ; 1981.

4. Габышева ЛП, Исаев АП. Влияние лесных пожаров на микроклиматические и почвенные условия лесов криолитозоны (Якутия, СевероВосточная Сибирь). Сибирский лесной журнал. 2015;(6):96-111.

5. Дубровская ОА, Мальбахов ВМ, Шлычков ВА. Влияние массовых лесных пожаров на циклонические процессы в Сибири. Вычислительные технологии. 2007;12(2):58-66.

6. Здерева МЯ, Виноградова МВ. Среднесрочный прогноз пожарной опасности в лесах по метеорологическим условиям. Метеорология и гидрология. 2009;1:16-26.

7. Зотов ОД. Эффект выходных дней в сейсмической активности. Физика Земли. 2007;12:27-34.

8. Иванов ВА, Коршунов НА, Матвеев ПМ. Пожары от молний в лесах Красноярского Приангарья. Красноярск: СибГТУ; 2004.

9. Исаев АС, Уткин АИ. Низовые пожары в лиственничных лесах Восточной Сибири и значение стволовых вредителей в послепожарном состоянии древостоя. В кн.: Защита лесов Сибири от насекомых-вредителей. М.: Изд-во АН СССР; 1963. с. 118-82.

10. Козлов ВИ, Муллаяров ВА. Грозовая активность в Якутии. Якутск: ЯФ Изд-ва СО PAH; 2004.

11. Кузнецов ВГ, Барановский НВ. Прогноз возникновения лесных пожаров и их экологи- ческих последствий. Новосибирск: Изд-во СО PAH; 2009.

12. Курбатский НП. Определение степени пожарной опасности в лесах. Лесное хозяйство. 1957;(7):53-7.

13. Латышева ИВ, Лощенко КА. Региональные особенности синоптических процессов на территории Иркутской области в 2000-2013 гг. Изв Иркутского гос ун-та сер Науки о Земле. 2015;(11):3-54.

14. Онучин АА. Леса бассейна Байкала (состояние, использование и охрана). Красноярск: Ин-т леса им. ВН Сукачева СО РАН; 2008.

15. Малевский-Малевич СП, Молькентин ЕК, Надёжина ЕД, Семиошина АА, Салль ИА, Хлебникова ЕИ, Шкляревич ОБ. К оценке изменений пожароопасной обстановки в леcax России при ожидаемом потеплении климата в XXI веке. Метеорология и гидрология. 2005;(3):36-44.

16. Мохов ИИ, Дюфрен Ж.-Л, Ле Трет Е. Изменения режимов засух и биопродуктивности наземных экосистем в регионах Северной Евразии по расчетам с глобальной климатической моделью с углеродным циклом. Докл PAН. 2005;405(6):810-4.

17. Мохов ИИ. Действие как интегральная характеристика климатических структур: оценки для атмосферных блокингов. Докл РАН. 2006;409(3):403-6.

18. Нестеров ВГ, Гриценко МВ, Шабунина ТА. Использование температуры точки росы при расчете показателя горимости леса. Метеорология и гидрология. 1968;(9):102-4.

19. Панина ОЮ. Исследование влияния лесных пожаров на почвы широколиственных лесов (на примере Еврейской автономной области). Региональные проблемы. 2010;13(1): 67-70. 
20. Побединский АВ. Сосновые леса Средней Сибири и Забайкалья. М.: Наука; 1965.

21. Сверлова ЛИ. Метод оценки пожарной опасности в лесах по условиям погоды с учетом поясов атмосферной засушливости и сезонов года. Хабаровск: ДВ УГМС; 2000.

22. Софронов МА, Волокитина АВ. Пирологическое районирование в таежной зоне. Новосибирск: Наука; 1990.

23. Суворов ЕГ. Проявление пирогенного фактора в динамике геосистем юго-западного Прибайкалья. География и природные ресурсы. 2008;(2):66-73.

24. Телицын ГП. Логарифмический показатель пожарной опасности для леса. Лесное хозяйство. 1970:(11);58-9.

25. Фуряев ВВ, Плешиков ФИ, Злобина ЛП, Фуряев ЕА. Трансформация структуры и экологических функций лесов Средней Сибири под воздействием пожаров. Лесоведение. 2004;(6):50-7.

26. Швиденко А3, Щепащенко ДГ, Ваганов ЕА, Сухинин АИ, Максютов ШШ, МкКаллум И, Лакида ИП. Влияние природных пожаров в России 1998-2010 гг. на экосистемы и глобальный углеродный бюджет. Докл РАН 2011;441(4):544-8

27. Шевцов ЕГ, Сухинин АИ, Пономарев ЕИ. Исследование влияния погодных условий на возникновение пожаров от гроз. Хвойные бореальной зоны. 2008;25(1-2):47-50.

28. Шешуков МА, Громыко СА, Позднякова BВ. Необходимость совершенствования комплексного показателя пожарной опасности в лесу по условиям погоды. Лесное хозяйство. 2007;(5):43-5.

29. Шубкин РГ, Осколков ВА, Воронин ВИ Метод дендрохронологии. Выявление крупномасштабных лесных пожаров и градаций хвоегрызущих насекомых. Лесное хозяйство. 2006;(2):45-7.

30. Щеглова ЕГ. О влиянии погодных условий на пожары природных объектов. Вестник ОГУ. 2013;1(150):166-70.

\section{Общий список литературы/Reference List}

1. Buzykin AI, Pshenichnikova PM. Formirovaniye Sosnovo-Listvennykh Molodniakov. [The Formation of Pine-Deciduous Young Stands]. Novosibirsk: Nauka; 1980. (In Russ.)

2. Valendik EN. Bor'ba s Krupnymi Pozharami [Fighting Major Fires]. Novosibirsk: Nauka: 1990. (In Russ.)

3. Vonsky SN, Zhdanko VA, Korbut VI. Opredeleniye Prirodnoy Pozharnoy Opasnosti v Lesu. [Estimating the Natural Fire Threat in a Forest]. Leningrad: LenNIILH;1981. (In Russ.)

4. Gabysheva LP, Isayev AP. [The influence of forest fires on soil and microclimatic conditions of the forests of the permafrost zone (Yakutia, northeastern Siberia)]. Sibirskiy Lesnoy Zhurnal. 2015;(6):96-111. (In Russ.)

5. Dubrovskaya OA, Mal'bakhov VM, Shlychkov VA. [The influence of mass forest fires on the cyclonic processes in Siberia]. Vychislitelnye Tekhnologii. 2007; 12(2):58-66. (In Russ.)
6. Zdereva MYa, Vinogradova MV. [Medium-term forecast of fire threat in forests according to meteorological conditions]. Meteorologiya i Gidrologiya 2009;(1):16-26. (In Russ.)

7. Zotov OD. [The weekend effect in seismic activity]. Fizika Zemli. 2007;(12):27-34. (In Russ.)

8. Ivanov VA, Korshunov ON, Matveev PM. Pozhary ot Molniy v Lesakh Krasnoyarskogo Priangar'ya. [Fires from Lightnings in the Forests of Krasnoyarsk Priangar'ye]. Krasnoyarsk: SibGTU; 2004. (In Russ.)

9. Isayev AS, Utkin AI. [Ground fires in larch forests of Eastern Siberia and the significance of stem pests in for the after-fire forest conditions]. In: Zaschita Lesov Sibiri ot Nasekomykh-Vrediteley. [Protection of Siberian Forests against Insect Pests]. Moscow: Izdatelstvo AN SSSR. 1963. P.118-82. (In Russ.)

10. Kozlov VI, Mullayarov VA. Grozovaya Aktivnost' v Yakutii. [Thunderstorm Activity in Yakutia]. Yakutsk: YaF Izdatel'stva SO RAN; 2004. (In Russ.)

11. Kuznetsov VG, Baranovskiy NV. Prognoz Voznignoveniya Lesnykh Pozharov i Ikh Ekologicheskirh Posledstviy. [Forecast of Forest Fires and Their Environmental Impacts]. Novosibirsk: Izdatel'stvo SO RAN; 2009. (In Russ.)

12. Kurbatskiy NP. [Determination of the degree of fire danger in forests]. Lesnoye Khoziaystvo. 1957;(7):53-7. (In Russ.)

13. Latysheva IV, Loshchenko KA. [Regional features of synoptic processes on the territory of Irkutsk Region in 2000-2013]. Izvestiya Irkutskogo Gosugarstvennogo Universiteta Seria Nauki o Zemle. 2015;(11):3-54. (In Russ.)

14. Onuchin AA. Lesa Basseyna Baykala (Sostoyaniye, Ispol'zobaniye i Okhrana). [Forests of the Baikal Basin (Their Conditions, Use, and Protection)]. Krasnoyarsk: V.N. Sukachev Forest Institute of SB of RAS; 2008. (In Russ.)

15. Malevsky-Malevich SP, Mol'kentin YeK, Nadezhina YeD, Semioshina AA, Sall' IA, Khlebnikova YeI, Shklyarevich OB. [On the assessment of changes in fire hazard situation in Russian forests under the expected climate warming in the XXI century]. Meteorologiya i Gidrologiya. 2005;(3):36-44. (In Russ.)

16. Mokhov II, Dufresne J-L, Le Trette E. [Changes in drought and bioproductivity regimes of terrestrial ecosystems in regions of Northern Eurasia according to calculations using a global climatic model with carbon cycle]. Doklady RAN. 2005;405(6):810-4. (In Russ.)

17. Mokhov II. [Action as an integral characteristic of climatic structures: Estimates for atmospheric backings]. Doklady RAN. 2006;409(3):403-6. (In Russ.)

18. Nesterov VG, Gritsenko MV, Shabunina TA. [The use of dew point temperature in the calculation of the indices of forest combustibility]. Meteorologia i Gidrologiya. 1968;(9):102-4. (In Russ.)

19. Panina OYu. [A study of the influence of forest fires on soil broad-leaved forests (as exemplified with the Jewish Autonomous Oblast)]. Regional'nye Problemy. 2010;13(1):67-70. (In Russ.) 
20. Pobedinsky AV. Sosnovye Lesa Sredney Sibiri i Zabaykal'ya. [Pine forests of Middle Siberia and Transbaikalia]. Moscow: Nauka;1965. (In Russ.)

21. Sverlova LI. Metod Otsenki Pozharnoy Opasnosti v Lesakh po Usloviyam Popody c Uchetom Poyasov Atmosfernoy Zasushlivosti i Sezonov Goda. [Method for Estimation of Fire Hazard in Forests Based Weather Conditions with Account of Atmospheric Aridity Zones and the Seasons of the Year]. Khabarovsk: DV UGMS; 2000 p. (In Russ.)

22. Sofronov MA, Volokitina AV. Biologicheskoe zoning in the taiga zone. Novosibirsk: Science. 1990: 204 p. (In Russ.)

23. Suvorov YeG. [The manifestation of the pyrogenic factor in the geosystem dynamics of the southwestern Baikal region]. Geografiya i Prirodnye Resursy. 2008;(2):66-73. (In Russ.)

24. Telitsin GP. [A logarithmic indicator of forest fire danger]. Lesnoye Khoziaystvo. 1970;(11):58-9. (In Russ.)

25. Furiayev BB, Pleshikov FI, Zlobina LP, Furiayev EA. [Transformation of structure and ecological functions of Middle Siberia forests under the influence of fires]. Lesoveden'ye. 2004;(6):507. (In Russ.)

26. Shvidenko AZ, Schepaschenko DG, Vaganov EA, Sukhinin AI, Maksyutov ShSh, McCallum I, Lakida IP. [The Influence of natural fires in Russia in 1998-2010 on ecosystems and the global carbon budget]. Doklady RAN. 2011;441(4):5448. (In Russ.)

27. Shevtsov YeG, Sukhinin AI, Ponomarev YeI. [Investigation into the effect of weather conditions on the occurrence of fires caused by lightnings]. Khvoynye Borealnye Zony. 2008;25(1-2):47-50. (In Russ.)

28. Sheshukov MA, Gromyko SA, Pozdnyakova VV. [The need to improve integrated forest fire danger indices according to weather conditions]. Lesnoye Khoziaystvo. 2007;(5):43-5. (In Russ.)

29. Shubkin RG, Oskolkov VA, Voronin VI. [The method of dendrochronology. Identifying largescale forest fires and gradations of coniferophagous insects]. Lesnoye Khosiaystvo. 2006;(2):45-7. (In Russ.)
30. Scheglova YeG. [The effect of weather conditions on natural objects fires]. Vestnik OGU. 2013;1(150):166-70. (In Russ.)

31. Bouguenaya N, Benyahia M, Bouzidi M. Synopsis of fire's forest in the Province of Sidi Bel Abbes. Analysis and cartography. J Agricultural Sci Technol. 2013;3:745-50.

32. Bovio G, Quaglino A, Nosenzo A. Individuazione di un indice di previsione per il pericolo. Monti e Boschi. 1984;4(35):39-44.

33. Carcaillet C, Bergeron Y, Richard PH. Change of fire frequency in the eastern Canadian boreal forests during the Holocene: does vegetation composition or climate trigger fire regime? J Ecol. 2001;89:930-46.

34. Ding Y, Ren G, Shi G. National climate change assessment report (I) Chinese climate change history and future trends. Climate Change Review. 2006;2(1):3-8.

35. Goncalves ZJ, Lourenco L. Meteorological index of forest fire risk in the Portuguese mainland territory. Proc Internat Conf Frest Fire Res. 1990;7:1-14.

36. Heikinheimo M. Renewing the system for forest fire risk assessment at the Finnish Meteorological Institute. Internat Forest Fire News. 1998;18:65-7.

37. Mollicone D, Eva HD, Achard F. Ecology: human role in Russian wild fires. Nature. 2006;440:436-7.

38. Pitkänen A, Huttunen P A. 1300-year forest-fire history at a site in eastern Finland based on charcoal and pollen records in laminated lake sediment. The Holocene. 1999;9(3):311-20.

39. Sol B. Estimation du risque meteorologique dincendies de forets dans le sudest de la France. Revue Forestiere Francaise. Numero special Escapes forestiers et incendies. 1990:263-71.

40. Stocks BJ, Simard AJ. Forest fire management in Canada. J Disaster Management. 1993;5(1):21-7.

41. Ward DE, Hardy CC. Smoke emissions from wildland fires. Environ Internat. 1991;17(2-3):117-34.

42. Zhao F, Shu L, Tian X. The forest combustible fuel dry conditions changes of Daxinanling forest region in Inner Mongolia under the climate warming. Ecol J. 2009;29(4):1914-20.

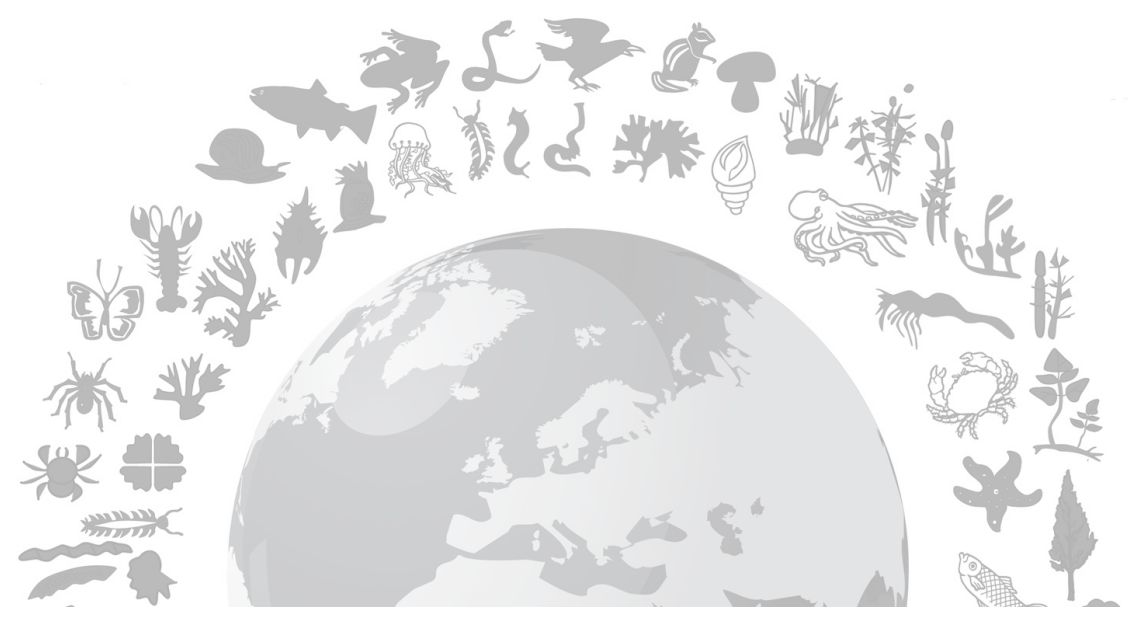

